$\mathrm{K}$

STUDIA Z PRAWA WYZNANIOWEGO

Tom $21-2018$

DOI: https://doi.org/10.31743/spw.185

\title{
THE STATE, SECTARIAN VIOLENCE, AND FREEDOM OF ASSOCIATION IN A SECULAR CONTEXT: THE CASE OF THE ISLAMIC MOVEMENT OF NIGERIA
}

\section{Summary}

This paper examines the interrelationship between the State, freedom of association and sectarian violence among faith communities in Nigeria. It specifically discusses the role of the State in maintaining peace, and the government's official response to sectarian violence among religious associations. In modern African states, sectarian violence has been prevalent and deadly among religious group movements. It is deployed as the most preferred means of attracting recognition, affirming feasibility and proclaiming existence among other religious associations in the State. This trend is associated with the Islamic Movement of Nigeria. It is against this background that this paper historicises sectarian violence, the myth and reality of religious freedom, the interrelationship between religious freedom, the State and secularism in Nigeria while discussing the constitutional provisions of religious freedom and religious associations in Nigeria. The paper concludes that religious freedom and freedom of association are integral features of the Nigerian Constitution and, therefore, all religious associations are permitted to live in peaceful coexistence.

Key words: the State; sectarian violence; freedom of association; Islamic Movement of Nigeria

$$
* * * * *
$$

* Doctor of Philosophy; Department of General Studies, Ladoke Akintola University of Technology, P.M.B 4000, Ogbomoso, Oyo State, Nigeria; e-mail: aaoladiti@lautech.edu.ng. 


\section{INTRODUCTION}

Nigeria is regarded as a secular state and, accordingly, "the government of the federation or of the state shall not adopt any religion as state religion" although, in reality, there is hardly any government programme unaffected by religious considerations. An example is the National Population Policy which prescribes the size of the nuclear family. Although the policy was aimed at curtailing the alarming increase in the population, it faced fierce opposition from the three major religious groups in Nigeria. They argued that it contravenes God's law of unlimited procreation and, based on this argument, the policy was not enforced as a state order. Other areas where government programmes have been affected by religious considerations is the provision of public holidays for religious feasts, conducting prayer sessions by religious bodies during official state functions for presidents or governors in the state, as well as spending public funds on religious pilgrimages and exempting religious bodies from tax payment. ${ }^{1}$

The notion that Nigeria is a "secular state" is controversial. This implies that the state should not accommodate any religious creeds and laws connected with "spiritual and religious matters." 2 This contradicts the provision of the Constitution which states clearly in its preamble that the people of the Federal Republic of Nigeria have firmly and solemnly resolved "to live in unity and harmony as one indivisible sovereign nation under God dedicated to the promotion of inter-African solidarity, world peace, international cooperation and understanding, and to provide for a constitution, for the purpose of promoting good government and welfare of all persons in our country on the principles of freedom, equality and justice and for the purpose of consolidating the unity of our people."3

The aforementioned phrase "under God" contradicts the characterization of Nigeria as a secular state. The Constitution further states that "in furtherance of the social order, the sanctity of the human person shall be

Olupona 1991, 31-45.

2 Ibidem.

3 The Constitution of the Federal Republin of Nigeria was published in vol. 86 in the Federal Republic of Nigeria Official (Extraordinary) Gazette on May 5, 1999, and came into force on May 29, 1999. 
recognised and human dignity shall be maintained and enhanced." The government of the Federal Republic of Nigeria promotes religious activities financially and in other ways. For instance, the federal and state governments of Nigeria on several occasions have used state resources to sponsor adherents of religious persons on pilgrimages to Mecca and Jerusalem. Besides, the federal government of Nigeria has also declared public holidays to mark popular religious feasts within the state. This indicates that Nigeria is not a secular but multi-religious state. ${ }^{4}$

The 1999 Constitution of the Federal Republic of Nigeria, section 38(1) declares that "every person shall be entitled to freedom of thought, conscience and religion, including freedom to change his religion or belief, and freedom (either alone or in community with others, and in public or private) to manifest and propagate his religion or belief in worship, teaching, practice and observance of one's religious belief without hindrance." This constitutional provision makes religious organisations under the law to apply Islamic Sharia law in the Muslim communities in northern Nigeria and the Christians are permitted to teach Christian religious studies in the schools in southern Nigeria. In addition, section 38(2) of the Constitution states that "no person attending any place of education shall be required to receive religious instruction or to take part in or attend any religious ceremony or observance if such instruction, ceremony or observance relates to a religion other than his own, or a religion not approved by his parent or guardian." This provision suggests that students shall not be forced to receive religious instruction, or take part in any religious activities other than the individual belief or religious orientation approved by their parents or guardians.

Similarly, section 38(3) of the same Constitution contradicts it, when it declares: "no religious community or denomination shall be prevented from providing religious instruction for pupils of that community or denomination in any place of education maintained wholly by that community." This implies that religious denominations shall not be prevented from providing religious instruction for all pupils of the religious community irrespective of their belief system as long as it is upheld by the community or denomination. This contradicts the earlier provision of the

4 Ekwenze 2016. 
Constitution that pupils shall not be forced to receive instruction or take part in any religious activities. Religious freedom is guaranteed through the liberty to education by a religious denomination, freedom of assembly and freedom of association in which practices such as night vigil, prayer sessions and congregational meetings, enrolment of students in schools are held among religious organisations with no restriction, even though such actions affect members of a close neighbourhood. ${ }^{5}$

In theory, the Nigerian state is responsible for the maintenance of law and order by ensuring peaceful coexistence and protecting the lives and property of people in the country. The state, in this context, is identified as comprising those institutions on which its actions have a stabilising effect. In Nigeria, the state has no locus standi to function and serve as a stabilising force among religious associations. Since the 1980s, the state has not been able to stop the acts of violence. This has continuously shaken the foundation of the country's national integration and peaceful co-existence, which can endanger cohesion in the social formation and distribution of values. ${ }^{6}$

Religious associations register with the Corporate Affairs Commission (CAC) before commencing public activities. By doing this, they subscribe to, and obey, the rules and order of the state before obeying the call to mission from God. These associations are responsible to their members more than the state. Indeed, the formation of religious associations is anchored in the preservation of doctrinal religious ideology and belief. ${ }^{7}$ This belief or ideology may not be shared by the state. It relies on the secular agency of the state, such as the $\mathrm{CAC}$, to grant it legal backing or powers to function. The CAC, operating under the Companies and Allied Matters Act, has the legal powers to incorporate, regulate, oversee, and even liquidate religious associations. The question that may arise from this is as follows: how does a secular agency of the state liquidate a religious association whose authority is usually embedded in the metaphysical or spiritual realm? The sovereignty of the state on religion and the incorporation of religious associations create further troubles, which this paper seeks to examine. This

\footnotetext{
Marshall 2013, 7-16.

Dunleavy and O'Leary 1987, 72-204.

7 Ukah 2015, 309-329.
} 
reality therefore calls for concern to re-examine the relationship between the state and Muslim religious associations in Nigeria.

\section{HISTORICAL BACKGROUND AND LITERATURE REVIEW}

In Nigeria, religious groups consider themselves as competitors and are at war with one another, which leads to inter- and intra-religious violence. This perception of competition and rivalry is crucial to understanding why violence occurs among religious bodies. According to Falola, religion has been disruptive to the relative peace enjoyed in the society since the 1970s. He explains that there have been more than a dozen serious religious riots, each claiming many lives and wreaking mass destruction on property and places of worship. Each riot ended up with the intervention of the police or military. In some instances, religious violence has divided local communities across Nigeria. The overbearing dominance of one religion over another, especially in the northern part of the country, has been one of the underlying factors leading to religious riots. The adherents of Islam and Christianity seek to unseat rival religions by imposing their own values and striving to control the state resources. This has led to the struggle for political power and use of religious and belief systems to influence the outcome of elections in Nigeria. In the 1979 general election in Nigeria, religion was used as a stepping-stone to power and political authority. During the election campaign, politicians urged their followers to vote along religious lines - Muslims were told to vote for Muslims and Christians for Christians. ${ }^{8}$

Between 1980 and the 1990s, there were outbreaks of riots leading to religious violence. In 1980, the Maitatsine riot claimed thousands of lives and churches were burnt by rival Islamic groups in the city of Kano. Indeed, intra-Islamic violence has led to the loss of lives and injury of hundreds of persons. In Ibadan, the Muslim Students' Society of Nigeria set fire to the sculpture of the Risen Christ on the premise that it was directly opposite the central mosque of the University of Ibadan. This action is an example of inter-religious violence in southern Nigeria; yet no serious government

8 Falola 1998, 1-23. 
effort has been made to achieve sustainable peace and stability, religionwise, in the country. It is therefore against this background that the notion that Nigeria is a "secular state," as written in the Constitution, is wrong. ${ }^{9}$

The term "secularism" purports that the country is officially neutral in matters relating to religion or supporting one religion or the other. In a secular state, citizens are treated equally regardless of religion. ${ }^{10}$ The state avoids preferential treatment of citizens on the basis of religion. It does not recognise an established religion or equivalent during state functions; it also maintains national governance without any influence from religious factions and vice versa. ${ }^{11}$ However, this is not the case in Nigeria. Barely is there any state function that does not feature a religious activity such as a Muslim and Christian prayer. If Nigeria were truly a secular state, such preference for religious bodies would not be allowed or accepted.

According to Gill, religion continues to play a significant role in the political life of people in many parts of the world. In human communities, people profess a strong alliance to various forms of spiritual faith or belief system. The resurgence of religious fundamentalism and "new religious politics" has led to the growing interest in the interrelationship between religious associations and the state. Religious associations have shown remarkable ability to mobilise collective action, including political protest, indicating that they are far from being politically or socially obsolete. In human history, the Roman Catholic Church is the world's longest-standing hierarchical organisation far outlasting any secular governing institution. The Catholic Church commands the loyalty of hundreds of millions of geographically-dispersed people without maintaining a standing army or police force. ${ }^{12}$

In a similar way to political systems, religious traditions have rules dictating who is a member of the spiritual community. Thus, religion incorporates authoritative relationships. Politicians in authority generally seek the means of preserving their power, while religious authority seeks to reach out to the state for support, as religious groups typically lack authoritative coercive power. In some instances, there is overlap of authority

\footnotetext{
Ibidem.

10 Omotola 2009, 81-98.

11 Olupona 1991, 31-42.

12 Gill 2001, 117-138.
} 
between state and religious leaders. Religious leaders may use their position to challenge an unpopular government as a means of preserving their authority or credibility among parishioners. ${ }^{13}$

Religion and state relations are social phenomena that influence human behaviour both as individuals and groups.${ }^{14}$ The relationship between religion and the state is greatly determined by the legal statutes of states. This may be determined by the religious diversification caused by the growth of religious values in a country and, at the same time, the dynamic new cultural orientation of people. ${ }^{15}$

Religion and the state is a well-defined field in legal history in many countries. In the view of Nieuwenhuis, the relationship between the state and religion has been studied from the perspective of the relationship between the State and the Church in medieval Europe. Notably, thoughts about this relationship have been changed in modern states in Africa. In medieval Europe, the Christian religion determined the position of the state as well as the position of the Church on issues relating to welfare of people, salaries of parish priests as well as the building and maintenance of Church activities. Christianity gave the state authority and legitimacy. In turn, the government protected the Christian faith by providing financial support in the construction of churches. ${ }^{16}$

In modern Europe, this practice has faded with the emergence of democracy and the rule of law. This point attests to the fact that the principles of religious freedom and equality of all persons play an important role in answering the question on how the state interacts with religion. One of the most important reasons for the continued interaction of religion and the state is the rising trend of large populations of religious people in the world. Religious interests provide the bases for participation or supporting one political party during elections against another. The social and cultural values of the people are determined by religious beliefs and sentiments. This has led to clashes between Christianity and Islam, with each struggling to get more converts. For this reason, it has become imperative for

13 Ibidem.

14 Sandal and Fox 2013, 13.

15 Ibidem.

16 Nieuwenhuis 2012, 153-174. 
the state to be involved in religious matters to protect lives and properties as well as maintain peaceful coexistence among citizens. ${ }^{17}$

Furthermore, in terms of societal organisation of religious bodies, the state is expected to collect taxes from religious groups, provide regulations for the organisation of ritual and religious processions within the state besides maintaining order and public peace and freedom of association among adherents of various belief systems. In different countries of the world, the relationship between the state and religion differs from one country to another. Similarly, the constitution of each country determines the limits of state involvement in religious matters. In the United States of America, the Constitution prohibits the existence of an established church. In Germany, article 137 of the Weimer Constitution (remaining in force on the basis of article 140 of the Basic Law for the Federal Republic of Germany) prohibits the existence of an established church, but states some religious denominations that may be recognised by the state. In England, the Anglican Church is the only established church recognised by the state. However, in the Netherlands, Church - State separation is assumed to be an unwritten principle of constitutional law, as the Constitution is silent on this issue. ${ }^{18}$

Legislation as well as case law in different countries of the world elaborates some other vital relationships between religion and the state. Winfried Brugger suggests six different models to explain the relationship. In the first one, the state is completely opposed to religion. Albania, where in the 1970s and 1980s religion was officially banned, is a good example. The second model is characterised by a "wall of separation" taken seriously not only in theory but in practice as well. Barring all religious signs from public education belongs here. The third model is less drastic: "separation" and "allowing for" are linked. In this case, the government neither advances nor obstructs religion. The fourth "combines separation with some kind cooperation;" the fifth covers formal unity of State and Church in the form of an established church, and the sixth deals with the State and the Church converging in a theocracy. ${ }^{19}$

At this point, it is important to ask the following questions: should the government allow religious symbols and religious references within the

\footnotetext{
17 Ibidem.

18 Ibidem.

19 Brugger 2009, 257.
} 
state? Or should civil servants be allowed to display their religious convictions at work? The answer to the first question is that religious symbols and references are part and parcel of people's religious belief and dignity. Since the right to religious freedom and right to be a member of a religious association, political party or religious body is in recognition of human rights, based on the principles of fairness, equity and good conscience, they should be allowed without any restriction. ${ }^{20}$

The exception is when an action infringes on the right and social wellbeing of others within a state. The answer to the second question has to balance two interests: the importance of government neutrality and the importance of freedom of religion, interests which play out differently in diverse countries. In France, for instance, strict state neutrality is seen as a necessary condition for freedom of religion outside the state domain. Therefore, freedom of religion has no substantial weight for a civil servant at work. Wearing religious symbols by civil servants is completely banned by law. The type of work is not relevant; nor does it matter if a civil servant has contact with the public or not. This situation in England differs widely in the sense that wearing a turban at work in the metropolitan police force is not prohibited; neither is wearing headscarves matching uniforms in public offices. In this instance, the civil servant's interest in manifesting his religion is less important than the state's interest in exercising authority without any appearance of religious preference. The constitutional principle of separation between the state and religion takes precedence; otherwise, this same authority would be undermined in a partly multi-religious society. Moreover, in specific cases, religious symbols may cause opposition to, or mistrust of, government actions. ${ }^{21}$

Another important relationship between the state and religion is the government's financial support to religious bodies, granting religious bodies tax waivers or tax exemption in some cases, especially in Nigeria. In Turkey, for instance, the directorate-general for religious matters appoints imams, and with this arrangement, the state authority is represented in the religious activity of the people in the state. In England, the crown has the power to appoint the bishops of the Church of England and to approve

20 Nieuwhenhuis 2012, 153-174.

21 Ibidem. 
certain church regulations. In France, the Catholic Bishops are appointed by the French President. Government involvement in religious matters becomes imminent when strongly dissenting views are preached. For instance, if preaching or teaching by a religious body switches to coercion or incitement, it could lead to government intervention. The government's restraint in criminalising dissenting opinions leaves open the possibility that the government itself promotes, defends and propagates liberal values.

Furthermore, the state is also involved in providing necessary finance to support religious activity. In many countries in Europe, government is the owner of many church buildings, but these buildings are at the disposal of religious associations. In France and the Netherlands, the government finances the construction of church and mosque buildings. ${ }^{22}$ In Germany, the tax department collects church tax from the members of the denominations recognised under public law. The church tax is $8 \%$ surcharge above the tax on wages. This regulation results in the national religious communities in Germany being among the richest religious communities in Europe. In Belgium, the government finances the maintenance of church buildings while the priests, reverends and rabbis receive state salary as well. This practice is restricted to recognised denominations in the state. In recent years, the imams in Belgium have been receiving state salary. It has been established from the foregoing that the government has no prominent role in religious activity except in matters relating to peace and stability of the state. Spiritual welfare is intimately a personal and institutional affair. The state becomes involved in state matters only when preaching switches to intimidation or incitement to violence; also, if a religion inspires criminal offences, then government intervention is mandatory. ${ }^{23}$

\section{SECTARIAN VIOLENCE IN AFRICA}

There are many instances of religious violence among members of the same religion in Africa. Differences among members of the same religion often lead to violence due to doctrinal differences, power struggle over

22 Maussen 2009, 181.

23 Nieuwhenhuis 2012, 153-174. 
appointments of leaders and inability to reach a consensus on theological matters. Sometimes the state sets one faction against another in order to promote general instability when it is politically expedient. ${ }^{24}$ Although Muslims in Nigeria commonly assert that there are no sects in Islam, there are profound differences and divisions among them. When these result in violence or political tension, they become difficult to conceal. The prevalent assumption among Christians in Nigeria that Islam is culturally and theologically monolithic is not right. ${ }^{25}$

Among Muslims and Christians, different sects, movements and religious bodies exist. These religious associations are often characterised by sharp doctrinal differences that may lead to violent conflicts. For instance, the violent sectarian conflicts between some religious associations, namely the Qadiriyyah and the Tijanniyya and the Jama'atu Izalatil Bid'ah wa Iqamatis Sunnah, commonly known as Izala and later known as the Islamic Movement of Nigeria (henceforth: IMN), are an important case to study. The missionary and de facto head of the organisation is Shaikh Ibrahim El-Zakzaky. The goal of the movement is to enlighten Muslims on their duties as individuals and to their community. The group owns more than three hundred primary and secondary schools located in different places, mainly in the northern region of Nigeria. They are known by the name Fuddiyya schools. This is in addition to many Islamic centres and other institutions. The movement also owns a media outlet, publishing one of the most widely-read newspapers in the Hausa language. ${ }^{26}$ Shaikh Ibrahim ElZakzaky, who has been arrested and charged for sedition or inciting disaffection to the government under the military and civilian governments, declares that "there is no government except that of Islam." 27 This statement is believed to be treasonable, which is an offence against the state and, therefore, he was declared wanted, arrested and imprisoned by the state.

Over the years, this association has involved strife and violence with other institutions of government, especially the Nigerian Army. On December 12, 2015, members of the IMN were on a religious procession in Kaduna

24 Ojo and Folarin 2008, 242-259. See also: Gabsis and Shaw 2014.

25 Falola 1998, 227-246.

26 Aliyu 2013, 310-327.

27 Falola and Genova 2009, 377-378. 
when troops of the Nigerian Army and the Chief of Army Staff were on the move to a peace mission assignment in Borno. The IMN members did not leave the road after subtle persuasion and a request to do so. The IMN members were attacked by the Army in self-defence. The intervention was performed in order to prevent breach of public peace and obstruction of the highway by the group. Sectarian violence is a form of communal violence inspired by sectarianism, that is, it occurs between different sects of a particular ideology or religion within a nation or community. These conflicts arise within religious groups of either Islam or Christianity. There are little or no records of violent attacks among the adherents of traditional religions in the society. Most of these conflicts are caused by power struggle, resource control, breakdown of security, regional interference and petty misunderstanding or rivalry between religious groups. African countries have experienced several episodes of sectarian violence and conflict. In Nigeria, for example, many of these conflicts have occurred in the northern part of Nigeria. The conflicts that took place in 1980-1985 are described by Toyin Falola as the "reign of terror." This shows the severity of violence in many northern cities during these years. ${ }^{28}$ Several eruptions of sectarian violence have occurred in Kano, Katsina, Zaria, Zango-Kataf, Kaduna, and Jos. These have led to the massive destruction of lives and property. In Somalia, Ahlu Sunnah Waljama'a is a Somali paramilitary group consisting of Sufis and moderates opposed to the radical Islamist group, A-Shabab. They fight to prevent the imposition of Wahabism on Somalia and to protect the country's Sunni-Sufi traditions and generally moderate religious views. ${ }^{29}$

The Central African Republic was plunged into turmoil in 2013 when Muslim rebels from the Seleka umbrella group seized power in the Christianmajority country. A band of mostly Christian militias, called the "anti-balaka," rose up to counter the Seleka. The Seleka ceded power to a transitional government in 2014 under international pressure, then months of violence followed, and the country was effectively partitioned, in spite of the presence of the UN peacekeeping force and the French mission. The country is undergoing an internationally-supervised transition involving a constitutional referendum as well as presidential and parliamentary elections. Similar viol-

28 Falola 1998, 227-246.

29 Gabsis and Shaw 2014. 
ence in Mali left several people dead and wounded in the village of Yerere. It began in 2011, when the Wahhabi Sunnis, while building a mosque, were attacked by followers of a more traditional strand of Islam in Mali. About 85\% of people in the country follow some form of Islam - ranging from secular moderates to stricter followers such as the Wahhabis. The Wahhabi wanted to build a mosque and had the necessary authorisation but other Muslim sects were opposed to it. ${ }^{30}$ This was basically a religious clash.

The wars in Sudan and Rwanda are classic examples of how religion affects the state; Islam was favoured in Sudan while Christianity was favoured in Rwanda. Although the two examples are not strictly speaking similar in terms of their factual situations, they provide explanation on how religious views affect state parochial interests. The war in Sudan has been principally on religious differences and has been described as "the worst humanitarian disaster in the world today." 31 The politics of Islamising the entire country, including the predominantly Christian south, plunged the country into war. This is closely related to what happened in Rwanda with the role played by the Catholic Church in the killings of over 800,000 Rwandans, with tens of thousands butchered by machete-wielding extremists and priests alike in a number of Catholic parishes in Rwanda where they took refuge. ${ }^{32}$ The Catholic parishes were the sites of mass killings during the Rwanda genocide. Twenty-two years after the brutal massacre that claimed thousands of lives, on Sunday November 20, 2016, the Catholic Church apologised for its role in the genocide. This apology is contained in a joint resolution signed by nine bishops representing all dioceses, which was to be read in all churches countrywide on Sunday as the end-ofyear message of the jubilee of God's mercy. ${ }^{33}$

\section{THE MYTH AND REALITY OF RELIGIOUS FREEDOM IN NIGERIA}

Religious freedom entails all activities relating to the rights, privileges and opportunities in the practice of religious duties. It covers all activities

\footnotetext{
30 Ibidem.

31 Ibidem.

32 Jakotade 2016.

33 Orlando 2012.
} 
of believers engaging in particular practices peculiar to religious observation in their diet, dress code, and prayer. It entails unrestricted access to worship, place of worship or time of worship and permits the religious people to maintain distinctive social organisations such as hospitals, family and welfare agencies, educational institutions and media outlets for the dissemination of religious information and advertising. ${ }^{34}$ Religious freedom does not permit any form of discrimination or attack on the grounds of religious extremism. It occurs when there are restrictions on religious activity subject only to such limitations as prescribed by law and necessary to protect public safety, order, health, morals or the fundamental rights and freedom of others. In addition, a religious ideology that contradicts the vision of the state may be repressed simply because the government wants no other centre of loyalty, allegiance or authority in the state. When this happens, it is a violation of religious freedom. ${ }^{35}$

Religious freedom is stereotyped by mythological conceptions and idealised realities in human societies. Mythological conceptions in this study are viewed as a popular religious-based conception which idealises the realities of religious freedom. Examples of myth on religious freedom are as follows. First, religious leaders implant their authority through a divine call from God and cannot be challenged. These leaders manifest a charismatic posture of oratory gifts. Second, religious leaders claim to have miracle healing powers and also possess the ability to foretell future events. Third, religious associations see themselves as charity organisations purposively created to donate to the poor and provide basic essential services such as healthcare and education. Religious bodies such as churches, mosques and other religious temples do not remit tax to the government on the premise that they are not profit-making ventures. Such religious bodies claim that tax exemption is a form of subsidy on religion. However, they operate with the logic of profits through benefits derived from gifts, tithes, as well as donations. ${ }^{36}$

In reality, the Nigerian Constitution guarantees freedom of worship as a basic right of citizens. Similarly, there is no specific institutional-

\footnotetext{
34 Johnson 2013, 17-24.

35 Ibidem.

36 Ben-Ner 1994, 731.
} 
ised hindrance to the right to worship in any part of Nigeria that can be defined as a genuine barrier to freedom of worship. The issue therefore is not to attempt to locate problems relating to the exercise of freedom of worship outside the laws of the land. ${ }^{37}$ Disputes over freedom of worship have basically not been about what the law provides or fails to provide. Freedoms of thought, conscience and religion or belief, including the rights to propagate, practise and teach are guaranteed. Citizens are protected from being compelled to receive religious instruction or to partake in religious ceremonies other than those to which they profess or subscribe. What this suggests is that disputes over the application of the provisions on freedom of worship, to the extent that they exist in that form, are social and political, not legal. Furthermore, with the implementation of Sharia law in the 12 northern states in Nigeria on civil matters, non-Muslims complained that it might be difficult to obtain permission for the construction of churches and building of Christian denominational schools in the northern regions. The Christians living in the region are in doubt, which makes them suspicious of the Muslims of northern Nigeria. ${ }^{38}$

Nigeria is a multi-religious country, characterised by different social categories which are substantially shaped by faith. It is important to ask the following question: do our problems come from the coexistence of different faiths and failure of the law to protect the exercise of freedom of worship, or are they symptoms of deeper social problems which are predicated on political competition for resources and power? The answer is that people misuse religion for personal motive(s). In Nigeria, people abuse religious rights and freedom, possibly because religious identities are manipulated by the state for political interests. The violence that Nigerians have been experiencing is not entirely the fault of religion, but the fault of the practitioners..$^{39}$ Religion, in a similar way to nationalism, can be used to unify or divide. The composition of Nigeria, with the 1914 amalgamation, can be seen as a foundational factor of the deep-rooted social problems which have led to struggles over resource control and power. ${ }^{40}$ In fact, there

\footnotetext{
37 Alao 2009, 297-312.

38 Liman 2009, 159-176.

39 Adekunle 2009c, 177-194.

40 Adekunle 2009a, 3-17.
} 
was no concrete desire by the people to live together as a corporate entity. The unity was imposed on them as an artificial creation by the British hegemony and this has continued to create enormous problems in searching for the unity of Nigeria. ${ }^{41}$

There are complaints about Muslims' and Christian Pentecostals' invasion of residential neighbourhoods from the educated elite who are worried about noise pollution. Many of the Pentecostal Churches and Muslim organisations use powerful hi-tech amplifiers, some of which are placed outside their premises to attract worshippers during crusades. All these contribute significantly to the noise level in urban cities. Almost all churches and mosques located in residential areas are culpable because, in addition to regular morning services, they also conduct night vigils. This is a great nuisance to the affected neighbourhoods. Litigations are rare because of the huge cost involved, but aggrieved residents take their cases to newspaper editors or call the police to mediate, often with limited success. This nuisance is widely discussed on the pages of national dailies with the educated elite calling on state and federal authorities to intervene and sanction the offending churches and mosques. ${ }^{42}$

Up till date, no serious state sanction has been enforced to guarantee religious freedom in the affected neighbourhoods. Efforts aimed at reducing the noise level among religious organisations were first undertaken in Lagos in 2005, when officials of the Lagos State Environmental Protection Agency met with religious leaders, both Christians and Muslims, warning them against the use of externally-placed loudspeakers. They were also ordered to ensure that the noise level does not exceed 55 decibels during the day and 45 decibels at night. It is further stipulated that early-morning service should not commence before 6.00 a.m. while mid-week services should not extend beyond 9.00 p.m. and should be performed without musical instruments. ${ }^{43}$

All these efforts by the government to address the issue of noise pollution have yielded little or no results due to the stiff opposition held by religious organisations against the state. Government intervention in reli-

\footnotetext{
41 Ibidem.

42 Adeboye 2012, 145-171.

43 Ibidem.
} 
gious activities, especially with respect to taxation and noise pollution, has continued to generate serious tension in the city in the sense that religious leaders complain of persecution by government authorities. Instead of addressing the issue of noise pollution, which the government regulation is aimed at enforcing, adherents of religious organisations strive to make the issue form of propaganda against the government. While the Lagos State government meant well in seeking a lasting solution to the noise pollution in the city, its selective approach played into the hands of religious leaders, especially within the context of the Nigerian state where Muslim-Christian and musical vendors are guilty of the same offence of noise pollution in the neighbourhood. ${ }^{44}$ Nevertheless, an important distinction needs to be made here. Many of the churches and mosques operating as worship centres are not subjected to strict laws under the Constitution to control the level of noise pollution in the worship centres. The debate regarding noise pollution seems to indicate the limitation of religious freedom in worship centres in the construction of citizenship rights and the responsibility of the state to maintain peace. ${ }^{45}$

In Nigeria, none of the major conflicts in the past was due to the exercise or denial of rights of individuals or groups to worship. This refers to conflicts arising specifically from overt and specific attempts of citizens to worship as they choose, or successful prevention of worship, or the imposition of another faith or mode of worship on citizens. Secondly, conflicts involving groups which assume religious dimensions are basically about power and resources (including land, access to state resources or institutions which empower individuals and/or groups). Thirdly, faith-based politics has become a major issue in the competition between fragments of the political elite, and faith is becoming increasingly a vital demographic index in the struggle for power and resources among the elite. Finally, Nigerian communities have always lived with multiplicity of religions, and the two largest religions, Islam and Christianity, have coexisted for more than a century with predictable stresses and tensions which, however, are not informed by the specific failure of the state to protect freedom of worship of citizens. ${ }^{46}$

\footnotetext{
44 Ibidem.

45 Nwaegulam 2000; Alao 2005; Awosiyan 2009.

46 Adekunle 2009b, 329-342.
} 
It will be misleading to assume, however, that no clashes of interests exists in matters relating to freedom of worship and social relations between the major religious groups in Nigeria. When faith boundaries converge around other issues which encourage competition for political power, control and accumulation and allocation of economic resources, faiths of competing groups are counted among victors or losers. Groups which prevail or predominate in particular geopolitical formations often define parameters for allocation of resources and act in such a manner that minorities feel that their interests are not protected by the majority. Often, the failure of the state to mediate in relations between groups identified by specific social demographics, such as faith, leads to stresses and conflict. ${ }^{47}$

There are also inevitable and endemic sources of friction which are part of the fabric of a multi-cultural and multi-religious nation. The Nigerian Constitution is built outside a religious context, and specifically demands that the state shall not adopt a religion. It operates on the basis of Nigeria being a multi-religious nation, and on the basis of multiplicity of legal systems which have their roots in Western, Islamic and traditional values. ${ }^{48}$ In the application of the law, conflict arises in the use of the legal orientation. The citizens interpret their social values to reflect in changes in the dynamics of multiple legal systems. For example, when many states in the north expanded the scope of Sharia, many Muslims welcomed it, and Christian groups worried over its likely impact on their lives. Importantly, not a single Christian has been deprived of his right to his faith since then, and it is arguable whether Muslims in the affected states have become better Muslims as a result of the changes. More significantly, hundreds of lives have been lost in riots and inter-religious conflicts because the elite in both religions have portrayed the development in terms of major achievements or setbacks for their respective faith. ${ }^{49}$

The politicisation of faith is now a major threat to national security and even the survival of the Nigerian nation. The insurgency of Boko Haram represents a clear example of anarchy of dangerous dimensions that is perhaps beyond the capacity of the security agencies to deal with

\footnotetext{
47 Ibidem.

48 Magashi 2015, 107-118.

49 Falola 1998, 227-246.
} 
effectively. ${ }^{50}$ These insurgents demand the elevation of Islamic faith politically as the fundamental guiding philosophy of the state. ${ }^{51}$ That position offends the concept and practice of the model Islamic society which existed in Medina during the life of Prophet Muhammad, which was a multireligious and multi-ethnic nation with a written constitution predicated on the consent by Christians, Jews and traditional religious adherents. ${ }^{52}$

In some parts of Nigeria, practices exist that restrict or hinder the application of religious freedom of worship of citizens. For example, such practices offend religious codes of dressing in schools, or rights of children and students to pray when they should; or discourage the training and deployment of particular religious subjects in schools in some states. Such practices discourage mixed living patterns but encourage and condone segregation of people of different faiths; they discourage citizens from building or having access to places of worship in areas where they are minorities; they discourage religious practices such as calling Muslims to prayers and congregations, or discourage Christian Churches from particular types of services or worship; they deliberately hinder the teaching or employment of religious instruction teachers in faith-based institutions. For instance, it is common practice that Islamic religious knowledge is not taught in primary and secondary schools owned by missionary bodies such as the Baptists, Anglicans, and Seventh-Day Adventists while Christian religious knowledge is likewise not taught in Islam-based institutions. ${ }^{53}$

In Osun State, one of the south-western Yoruba towns in Nigeria, the Muslim community and the Muslim Students' Society of Nigeria sought the order of the court to allow female Muslim students to enjoy their fundamental right to use hijab (Muslim female style of dressing of covering the head and other parts of the body leaving the hands, face and legs) in public primary and secondary schools. The court ruled in favour of the use of hijab. The decision of the court was not found acceptable to members of the Christian Association of Nigeria, Osun State chapter, so immediately the after the judgment was pronounced, the association ordered Christian

\footnotetext{
50 Muzan 2014, 217-243.

51 Kane 2003, 274.

52 Rafiu 2016, 461-462.

53 Ibidem.
} 
pupils to appear in school in church attire. This reaction from the Christians implies their unwillingness to allow Muslim female students to use hijab in public secondary schools.

In Nigeria, the government usually declares public holidays during religious feasts and ceremonies commemorating some important events in religious life. The days of religious feasts among faith communities are recognised in Nigeria by exempting people from labour and businesses from operation, suspending the business of governance, closing court rooms as well as allowing non-observance of legal and educational activities in the country. According to the Interpretation Act of the 1999 Constitution on public holidays, section 4, it is only the Federal Government of Nigeria that can legislate on public holidays. The state government only declares public holidays when the need arises but not on the basis of legislation.

\section{RELIGIOUS FREEDOM, THE STATE AND SECULARISM IN NIGERIA: THE CASE OF THE ISLAMIC MOVEMENT OF NIGERIA}

Religious freedom is guaranteed in the Constitution of the Federal Republic of Nigeria. Nigerians are free to practise the religion of their choice and no religious groups or associations are favoured or discriminated against, except that secret societies are prohibited. This attitude provides the bases for religious tolerance and diversity in the religious growth of people. At independence in 1960, Nigeria recognised all religious faiths. The religious faith served to provide a certain degree of social and political harmony. It expresses the overarching values and precepts to which a particular nation subscribes and integrates all religious, moral and political values. ${ }^{54}$

Nigeria is a multi-religious society. No single religion is officially recognised as the state religion. Hence, what the Nigerian State has is what Rosalind Hackett and Jacob Olupona have described as "civil religion," a religious belief premised to promote religious pluralism and national integration within the states and federating units in the country. ${ }^{55}$ The myth, ritual and the history of this type of religion will be discussed. The concept

54 Hackett and Olupona 1991, 265-281.

55 Ibidem. 
of civil religion was first employed by Jean-Jacques Rousseau in his seminal work on social contract: "there is purely civil profession of faith, the articles of which it behoves the sovereign to fix, not with the precision of religious dogmas but treating them as a body of social sentiments without which no man can either be a good citizen or a faithful subject." 56

This idea was later popularised in the writings of Emile Durkheim on the elementary forms of religious life, where he states that any coherent society must rest on a set of moral beliefs and shared values that form the collective conscience of the nation. In their absence, there will be no social order, social control, social solidarity, cooperation and national integration. ${ }^{57}$ Both implicitly and explicitly in action and practice, the State and federal government have used the word "God" in public pronouncements and utterances during inauguration ceremonies and on religious public national holidays. ${ }^{58}$ The American sociologist Robert Bellah explains that the "civil faith" consists of a loose collection of rites, ceremonies, and beliefs derived from, and pertaining to, the collective experience and destiny of a particular nation. While the concept of civil religion has been discussed and elaborated within the American context, there have been more developments recently to connect it with similar trends emerging in developing countries. ${ }^{59}$ It is argued in this paper that there are definite signs of the practice of civil religion in Nigeria.

The Islamic Movement of Nigeria has its origin in the Muslim Students' Society in Ahmadu Bello University Zaria, in Kaduna State. It came into existence as a result of the political activities of Yan' Izalatin in the 1970s. The IMN is a Muslim organisation in Zaria with its headquarters as the Fuddiyyah Islamic Centre since 2002. It was founded and led by Sheikh Ibrahim El-Zakzaky. The organisation is also known as the Nigerian Muslim Brothers. The Nigerian media have described this group as Shiites due to the political views and massive support the organisation receives from Iran. Members of the group have openly converted to Shiism by celebrating the feast of ashura and Fatima's birthday. This practice openly

56 Rousseau 1960, 305-306.

57 Holborn and Haralambos 2008, 397.

58 Durkheim 1912, 427.

59 Bellah 1974, 225. 
displays their commitment to the Shiite doctrinal belief which is different from the Sunni religious practice, although members of the movement identify themselves as Sunni Muslims. The main goal of the movement is to enlighten Muslims about their individual and communal duties. The movement owns and operates hundreds of schools known as Fuddiyyah schools throughout the northern part of Nigeria. It also owns Al-Mizan, a widely-distributed Hausa-language newspaper. The movement has expanded its scope beyond education to cover other areas such as healthcare services. It has a medical team which provides healthcare services to members of the community. It is believed that there are over a million of members of the organisation. ${ }^{60}$

This IMN de-emphasises the political option of the northern ruling class of the state and rejects the status quo of the conservative and corrupt Nigerian kleptocratic officers using the Nigerian Constitution for the governance of the State. The movement pursues the goal of establishing an Islamic State. The founder of the movement and his group do not believe that an Islamic State could be established in a democratic or semi-secular state such as Nigeria. Sheikh Ibrahim El-Zakzaky opposes the political Islam found in some northern states of Nigeria because, as he explains, "the process cannot operate under a superior authority which the Constitution represents." ${ }^{\prime 1}$

\section{THE CONSTITUTIONAL PROVISIONS ON FREEDOM OF ASSOCIATION IN NIGERIA (CASE STUDIES)}

Section 40 of the Nigerian Constitution states that citizens of Nigeria have the right to assemble freely and associate with other persons, and in particular, an individual may form or belong to any political party, trade union or any other association for the protection of his interests. However, section 45 of the Nigerian Constitution notes that "nothing of the Constitution relating to section 40 invalidates any law that is reasonably justifiable in a democratic society in the interest of defence, public safety, public or-

\footnotetext{
60 Kane 2003, 274.

61 Ibidem.
} 
der, public morality, public health or for the purpose of protecting the rights and freedom of other persons." This is cited as the main constitutional provision for the Muslim rights to assembly and association.

This was manifested in the case of Miss Asiyat Abdulkareem, Miss Maryam Oyeniyi and the Muslim Students' Society of Nigeria (religious association) v. Lagos State Government, Hon. Attorney-General and Commissioner of Justice, Hon. Commissioner of Education, Lagos State and Hon. Commissioner of Home Affairs and Culture, Lagos State. The appellate court held in its judgement that the use of hijab (Muslim female dressing) is an observance of Islamic religious doctrine which also constitutes an act of worship in Islamic religion. The court argued that there was a violation of rights denying the appellant Miss Asiyat Abdulkareem and Miss Maryam Oyeniyi the opportunity to receive religious instruction in accordance with the religion approved by their parents or guardian. ${ }^{62}$

The appellate court affirmed that the Constitution guarantees the right to freedom of thought, conscience and religion. By virtue of this provision, a person is free in private or public to manifest, uphold and practise the belief and doctrine of his or her religious association. The limit to this is when it impinges on the rights of others or where they put the welfare of the society or public health in jeopardy. The respondents did not tender any convincing evidence or statutory instrument prohibiting the wearing of hijab on school uniforms at the lower court. The court held that the refusal by the respondents to allow the female Muslim students to wear hijab on their school uniform, either during or after school hours, is an infringement of their constitutionally-guaranteed right. The judgment of the lower court in favour of the plaintiff was set aside at the appeal court in Lagos State on the grounds that the refusal to allow the appellant to wear hijab discriminated against the Muslim females due to their associational and religious belief. ${ }^{63}$ This Muslim Students' Society was founded by young Yoruba Muslims who felt oppressed because of their religious affiliation. This state of affairs culminated in the Anglican Synod decision to expel all Muslim students attending Christian schools,

${ }^{62}$ Asiyat Abdulkareem and ors v. LASG and ors. July 21, 2016. Court of Appeal. Lagos Judicial Division.

63 Ibidem. 
probably sometime in $1954 .{ }^{64}$ Although not all Muslim pupils were ultimately expelled, Yoruba Muslims from then on abstained from publicly professing their faith or practising it or even using their Muslim names in the Christian schools they were attending. Under these circumstances, 40 Muslim students from seven different secondary schools, one of them a Muslim school, represented their Muslim schoolmates at a meeting that resulted in the establishment of the Muslim Students' Society on April 17, 1954. Three years later, in 1957, the Muslim Students' Society had set up local sections in schools throughout the Western Region and University of Ibadan, the first university established in Nigeria. Although the Muslim Students' Society in Yorubaland was originally a movement of self-assertion, it became in due course a radical Islamist movement in northern Nigeria. Among the consequences of the generalisation of formal education was the multiplication by tenfold of the student population and, thus, a substantial increase in the potential constituency of student movements. However, the mere increase of student population socialised in new values and nurturing aspirations of a different kind from their parents may not have resulted in the assertion of Islamic identities as was the case in northern Nigeria, had the national and international contexts not been conducive to such development. ${ }^{65}$

But this is not the case when examining section 38(4) of the 1999 Constitution, which states that "nothing in this section shall entitle any person to form, take part in the activity or be a member of secret society." This constitutional provision does not respect the rights of African traditional worshippers for whom membership in a secret society is encouraged as part of the doctrinal belief system. Egbe Ogboni in Abeokuta, Ekpe among Ibibio and Agemo and Osugbo cults in Ijebu-Ode are examples of traditional secret societies founded in Nigeria. ${ }^{66}$ The constitutional provision and statement that no person shall form, or take part in, or be a member of, a secret society contradicts the right to assembly and freedom of association. The right to assembly and association is intended

64 Tajudeen 1984, 4.

65 Kane 2003, 73-74.

66 The Ogboni, Ekpe, Agemo and Osugbo cults are socio-politico traditional cults found among the Egba and Ijebu Yoruba groups and the Ibibio peoples in Nigeria. 
in the Constitution to promote freedom, equality and justice. But this is not the case in section 38(4) of the Constitution, which does not guarantee a general right to peaceful assembly or association as it is practised in the indigenous African traditional belief systems among various ethnic groups in Nigeria. ${ }^{67}$ In the case of the Registered Trustees of Rosicrucian Order (AMORC) v. Henry Awoniyi, Gabriel Abikoye, ECWA Productions Limited and Caxton Press (W.A) Limited, the Supreme Court of Nigeria held that AMORC is a secret society closely associated with mysticism, astrology, knowledge or use of the supernatural through scientific studies and experiments and the use of astral projection, as can be attested by their various publications. This example fits into the definition of a secret society, which is a typical example of a religious association in the context of African traditional religion as contained in section 35(4) of the 1999 Constitution. ${ }^{68}$

In Nigeria, "religious associations share similar characteristics with the State." For example, both agencies serve as structures for mobilisation of sentiments and values (e.g. patriotism, commitment) as well as sources of power in the right to mete out punishment and control resources, such as money and allegiance, and compete for citizens' loyalty. State sovereignty and governance are structured relative to the acceptance of the idea that religion is a separate sphere of human conduct that requires separate laws and special policies to manage and control. ${ }^{69}$

${ }^{67}$ On the right to freedom of thought, conscience and religion, see section 38(1-4) of the 1999 Constitution of the Federal Republic of Nigeria. The Registered Trustees of Rosicrucian Order (AMORC) v. Awoniyi (1994), 7 Nigeria Weekly Law Report (PT 355), 154. See also the case of Agbai v. Okagbue (1991), 7 Nigeria Weekly Law Report (PT 204), 391.

68 Here, the appellant as plaintiff sued the respondent and cross-appellant for libel, which allegedly arose from three published issues of a news magazine called Today's Challenge. The offending articles were published in the March/April, May/June, and July/August editions of the magazine in 2002 (vol. 7, edition 10). In the first edition under reference, the Rosicrucian Order (AMORC) was variously described as secret and sinister. The May/June edition called it satanic in teaching and doctrine, while the July/August edition described H. Spencer Lewis as a liar, hypocrite, swindler, egoistic charlatan and a man without any modicum of honour or integrity. AMORC sued the publishers of the magazine and claimed \#10 million as special and general damages.

69 Ukah 2015, 309-329. 


\section{CONCLUSION}

It has been established from the foregoing that the relationship between Muslim religious associations in Nigeria has no locus standi in stabilising religious activities, especially during worship, in situations where it affects the right of others living in the same community. The Nigerian case is an important reference point of study because the State has not provided the cohesion required for social formation in the distribution of values that would ensure the maintenance of peace and stability among various religious associations in Nigeria. The scarce resources belonging to the State are expended on religious activities. Although Nigeria claims to be a secular state through its provision in the Constitution, there is hardly any government programme unaffected by religious considerations. This explains how religious associations have been manipulated by the State to control the people for personal gains.

\section{REFERENCES}

Adeboye, Olufunke. 2012. "«A church in a cinema hall?» Pentecostal appropriation of public space in Nigeria." Journal of Religion in Africa 42, no. 2: 145171, http://dx.doi.org/10.1163/15700666-12341227

Adekunle, Julius O. 2009a. "Introduction: Religion and politics in transition." In Religion in Politics: Secularism and National Integration in Modern Nigeria, edited by Julius O. Adekunle, 3-17. Trenton, New Jersey: Africa World Press. Adekunle, Julius O. 2009b. "Government reaction to religious violence." In Religion in Politics Secularism and National Integration in Modern Nigeria, edited by Julius O. Adekunle, 329-342. Trenton, New Jersey: Africa World Press.

Adekunle, Julius O. 2009c. "Religion, politics and violence." In Religion in Politics: Secularism and National Integration in Modern Nigeria, edited by Julius O. Adekunle, 177-194. Trenton, New Jersey: Africa World Press.

Alao, Akin. 2009. "The judiciary and religious freedom: constitutional guarantee of the secularity of the state." In Religion in Politics: Secularism and National Integration in Modern Nigeria, edited by Julius O. Adekunle, 297-312. Trenton, New Jersey: Africa World Press.

Alao, Tunde. 2005. "Lagos meets religious leaders, unveils new noise regulation," Guardian, April 6, 2005. 
Aliyu, Muhammad Tanko. 2013. "The challenges of Islamic organisations in Nigeria, 1960-2010." In Thoughts in the Humanities, edited by R.A. Akanmidu, 310-127. Ilorin: University of Ilorin.

Awosiyan, Kunle. 2009. "Lagos seals off redeemed, mountains of fire over «noise pollution»," Tribune, October 21, 2009.

Bellah, Robert. 1974. “American civil religion.” In American Civil Religion, edited by Russel E. Richey and Donald G. Jones. New York: Harper and Row.

Ben-Ner, Avner. 1994. "Who benefits from nonprofit sector? Reforming law and public policy towards nonprofit organizations." The Yale Law Journal 104, no. 3: 731-762, http://dx.doi.org/10.2307/797116

Brugger, Winfried. 2009. "From hostility through recognition to identification: state-church models and their relationship to freedom of religion." In Secularization and World Religions, edited by Hans Joas and Klaus Wiegandt. London: Liverpool University Press.

Durkheim, Emile. 1912. The Elementary Forms of the Religious Life. New York: The Free Press.

Dunleavy, Patrick, and Brendan O'Leary. 1987. Theories of the State: the Politics of Liberal Democracy. London: Macmillan.

Ekwenze, Solomon A. M. 2016. "Nigeria's multi-religious platform: a myth or reality - public holidays a question" (September 7, 2016), http://dx.doi. org/10.2139/ssrn.2838827.

Falola, Toyin. 1998. Violence in Nigeria: the Crisis of Religious Politics and Secular Ideologies. Rochester, New York: Rochester University Press.

Falola, Toyin, and Ann Genova. 2009. Historical Dictionary of Nigeria (Lanham, Maryland - Toronto - Plymouth, UK: The Scarecrow Press, Inc.

Gabsis, Sohaib, and Scott Shaw. 2014. "Crisis in the Central African Republic: Muslim Minorities and the Descent into Sectarian Conflict." Paper prepared for the All-Parliamentary Group for the Prevention of Genocide and other Crimes against Humanity. Carleton University and the Norman Peterson School of International Affairs. June 17, 2014. Accessed December 29, 2017. https://carleton.ca/cifp/wp-content/uploads/A-Briefing-Note-on-the-Conflictin-Central-African-Republic.pdf.

Gill, Anthony. 2001. "Religion and comparative politics." Annual Review of Political Science 4: 117-138, https://doi.org/10.1146/annurev.polisci.4.1.117

Hackett, Rosalind, and Jacob K. Olupona. 1991. "Civil religion." In Religion and Society in Nigeria: Historical and Sociological Perspectives, edited by Jacob K. Olupona and Toyin Falola, 265-281. Ibadan: Spectrum Books.

Holborn, Martin, and Mike Haralambos. 2008. Sociology: Themes and Perspectives. London: Harper Collins Publishers Limited. 
Jakotade, Olumide. 2016. "Rwanda genocide: how religion may have aided the massacre of over 500,000 Tutis," November 29, 2016. Accessed December 29, 2017. http://venturesafrica.com/catholic-church-rwandan-genocide/.

Johnson, Thomas K. 2013. "Religious freedom and the twofold work of God in the world." International Journal of Religious Freedom 6, no. 1/2: 17-24.

Kane, Ousmane. 2003. Muslim Modernity in Postcolonial Nigeria: a Study of The Society for the Removal of Innovation and the Reinstatement of Tradition. Leiden-Boston: Brill.

Liman, Saadatu Hassan. 2009. "Sharia and politics: crisis, conflicts and resolutions." In Religion in Politics: Secularism and National Integration in Modern Nigeria, edited by Julius O. Adekunle, 159-176. Trenton, New Jersey: Africa World Press.

Magashi, Salim Bashir. 2015. "Pluralism in the Nigerian legal system as a panacea for an inclusive national development." In Law and Religion in Africa: the Quest for Common Good in Pluralistic Societies, edited by Pieter Coertzein, M. Christian Green and Len Hansen, 107-118. Stellenbosch: Sun Media.

Marshall, Paul. 2013. "Conceptual issues in contemporary religious freedom research," International Journal for Religious Freedom 6, no. 1/2: 7-16.

Maussen, Marcel. 2009. Constructing Mosques: the Governance of Islam in France and the Netherlands. Amsterdam: Amsterdam School for Social Science Research.

Muzan, Allswell Osini. 2014. "Insurgency in Nigeria: addressing the causes as part of the solution." African Human Rights Law Journal 14: 217-243.

Nieuwenhuis, Aernout J. 2012. "State and religion, a multidimensional relationship: some comparative law remarks." International Journal of Constitutional Law 10, no. 1: 153-174, https://doi.org/10.1093/icon/mos001.

Nwaegulam, Chinedu. 2000. "Lagos seals off churches over noise pollution," Vanguard, August 16, 2000.

Olupona, Jacob K. 1991. "Contemporary religious terrain." In Religion and Society in Nigeria: Historical and Sociological Perspectives, edited by Jacob K. Olupona and Toyin Falola, 31-45. Ibadan: Spectrum Books Limited.

Ojo, Olusola, and Sheriff Folarin. 2008. "The limits of state sovereignty: Darfur crisis and the United Nations." Jadavpur Journal of International Relations 11-12, no. 6: 242-259, https://doi.org/10.1177/0973598408110013.

Omotola, Shola. 2009. "Beyond secularism: the shadow of religion on Nigerian democracy." In Religion and Politics: Secularism and National Integration in Modern Nigeria, edited by Julius O. Adekunle, 81-98. New Jersey: Africa World Press.

Orlando, Alissa. 2012. "The Catholic Church bears guilt for the horrors of the Rwanda genocide," JYAN Blog, March 5, 2012. Berkeley Centre For Religion, 
Peace and World Affairs. Georgetown University. Accessed December 29, 2017. https://berkleycenter.georgetown.edu/posts/the-catholic-church-bears-guilt-forthe-horrors-of-the-rwandan-genocide

Rafiu, Adebayo Ibrahim. 2016. "Engendering religious tolerance and nation building: the view of Dawood Adekilekun Tijani." In The Heritage of Islam in Nigeria: Essays in Memory of Dr. Dawood Adekilekun Tijani 1942-2006, edited by Siyan Oyeweso, Mikhail Adebisi Folohunsho and Rafiu Adebayo, 461-462. Osogbo: Mega press LTD.

Rousseau, Jean-Jacques. 1960. "Of civil religion.” In Social Contract, edited by Ernest Barker, 305-306. London: Oxford University Press.

Sandal, Nukhet, and Jonathan Fox. 2013. Religion in International Relations Theory: Concepts, Tools and Debates. London: Routledge.

Tajudeen, Abu Bakr. 1984. The Muslim Student Society: Thirty Years After. Ibadan: Islamic Book centre of UIMSS.

Ukah, Asonzeh. 2015. "Obeying Caesar to obey God: the dilemmas of registering of religious organisations in Nigeria." In Law and Religion in Africa: the Quest for the Common Good in Pluralistic Societies, edited by Pieter Coertzen, M. Christian Green and Len Hansen, 309-329. Stellenbosch: Sun Media.

\section{PAŃSTWO, PRZEMOC O PODŁOŻU RELIGIJNYM \\ I WOLNOŚĆ STOWARZYSZANIA SIĘ W ŚWIECKIM KONTEKŚCIE: KAZUS ISLAMSKIEGO RUCHU NIGERII}

Streszczenie

Artykuł dotyczy związków pomiędzy państwem, wolnością stowarzyszania się oraz aktami przemocy o podłożu religijnym, do jakich dochodzi pomiędzy grupami wyznaniowymi w Nigerii. Poświęcony jest w szczególności roli państwa w utrzymaniu pokoju oraz oficjalnej reakcji rządu na wspomnianą przemoc. We współczesnych państwach afrykańskich przemoc o podłożu religijnym jest bardzo częstym i niebezpiecznym zjawiskiem charakteryzującym relacje pomiędzy grupami religijnymi. Używa się jej jako preferowanego środka przyciągania uwagi, potwierdzania skuteczności działania i zapewniania sobie miejsca wśród innych wspólnot religijnych w państwie. Ten trend kojarzony jest z Islamskim Ruchem Nigerii. W tym kontekście artykuł przedstawia historię przemocy o podłożu religijnym, mit i rzeczywistość wolności religijnej, związki pomiędzy wolnością religijną, państwem i sekularyzmem w Nigerii, jednocześnie analizując obowiązujące w tym państwie konstytucyjne przepisy o wolności religijnej i wolności stowa- 
rzyszania się. W konkluzji stwierdza się, że wolność religijna i wolność stowarzyszania się stanowią integralne elementy nigeryjskiego porządku konstytucyjnego, a w związku z tym wszystkie wspólnoty religijne mają prawo do pokojowego współistnienia.

Slowa kluczowe: państwo; przemoc o podłożu religijnym; wolność stowarzyszania się; Islamski Ruch Nigerii

Ttumaczenie: Daria Bębeniec 